\title{
Freight Bogie Prototype Properties Analysis by Means of Simulation Computations
}

\section{Pavol Št’astniak ${ }^{1}$, Marián Moravčík ${ }^{2}$}

${ }^{1}$ Faculty of Mechanical Engineering, University of Žilina, 01026 Žilina. Slovak Republic. E-mail: pavol.stastniak@fstroj.uniza.sk,

${ }^{2}$ Tatravagónka a.s., Štefánikova 887/53, 05801 Poprad. Slovak Republic. E-mail: marian.moravcik@tatravagonka.sk.

The object of this article is to analyse the stability of changed three axle rail bogie structure, which is characterized below by higher axle loads combined with good operational properties. The occasion of change was the unstable behaviour of the system during prototype development. For validation of the structure design, there has been created a substitute simulation model in program Simpack, by which the computations were performed for partial system. Model represents only elasto-kinematic properties of the system. For stability analysis of the system, there have been a set of boundary conditions from different degrees of freedom to state out of balance. Simulation calculations show, that up to one oscillation in the y-direction, which is damped in real bogie by friction in suspension and dampers Lenoir, is the system after all deflections in initial condition. Substantial unstable behaviour does not show already.

Keywords: Stability Analysis, Bogie Prototype, Balance Beams, Simulation Computations.

\section{Acknowledgement}

This paper was created in accordance to the processing of the project "RAILBCOT - RAIL Vehicles Brake COmponents Test Stand”, ITMS Code 26220220011 based on the support of Research and Development Operational Program co-financed from EU sources. The work was also supported by the project No. APVV-0842-11: "Equivalent railway operation load simulator on the roller rig”.

\section{Research-Educational Centre of Rail Vehicles (VVCKV)}

This paper was created in accordance to the processing of the project "Development of two types of freight wagons with bogies for non-standard wheelbase or track wheelset, complying with the criteria for interoperability, Environmental Issues, safety and reliability ", ITMS Code 26220220070 based on the support of Research and Development Operational Program co-financed from EU sources.

\section{References}

[1] DIŽO, J., HARUŠINEC, J., BLATNICKÝ, M. (2015). Multibody system of a rail vehicle bogie with a flexible body. In: Manufacturing technology: journal for science, research and production. - ISSN 1213-2489. - Vol. 15, No. 5 (2015), pp. 781-788.

[2] DIŽO, J., BLATNICKÝ, M. (2016). Use of multibody system dynamics as a tool for rail vehicle behaviour diagnostics. In: Diagnostyka. - ISSN 1641-6414. - Vol. 17, No. 2 (2016), pp. 9-16.

[3] EN 13749 (2011). Railway applications - Wheelsets and bogies - Method of specifying the structural requirements of bogie frames. European Committee for Standardization.

[4] GERLICI, J., LACK, T., HARUŠINEC, J. (2013). The Test Stand Load Modulus Implementation for the Realistic Railway Operation in the Laboratory Conditions. In: Manufacturing technology: journal for science, research and production. - ISSN 1213-2489. - Vol. 13, No. 4 (2013), pp. 444-449.

[5] KLIMENDA, F., SKOČILASOVÁ, B. (2015). Rollers vibration of pipe conveyor. In: Manufacturing technology: journal for science, research and production. - ISSN 1213-2489. - Vol. 15, No. 6 (2015), pp. 991-995.

[6] KLIMENDA, F., SOUKUP, J., ŽMINDÁK, M. (2016). Deformation of Aluminium Thin Plate. In: Manufacturing Technology. Journal for Science, Research and Production. Vol. 16, No. 1. ISSN 1213-2489.

[7] KALINČÁK, D. (2015). Modern design of freight bogies. In: Technológ. - ISSN 1337-8996. Vol. 7, No. 2 (2015), pp. 76-81.

[8] LACK, T., GERLICI, J. (2015). Railway bogie properties analysis by means of simulation computations. In: Railway transport and logistics. - ISSN 1336-7943. - No. 11, Vol. 2 (2015), online, pp. 54-60.

[9] LACK, T., GERLICI, J., MAŇUROVÁ, M. (2014). Dynamic properties analysis of freight bogie model I. In: Innovations in the concept, design, manufacturing and testing of freight wagons I.: 27 - 28 November 2014, Žilina: Proceedings, University of Žilina, 2014. - ISBN 978-80-554-0955-9. - pp. 65-74. 
[10] LACK, T., GERLICI, J., MAŇUROVÁ, M. (2015). Dynamic properties analysis of freight bogie model II. In: Innovations in the concept, design, manufacturing and testing of freight wagons II.: 29 - 30 January 2014, Žilina: Proceedings, University of Žilina, 2015. - ISBN 978-80-554-0980-1. - pp. 51-56.

[11] NANGOLO, F., N., SOUKUP, J. (2014). The Effect of Asymmetry on Vertical Dynamic Response of Railway Vehicles. In: Manufacturing technology: journal for science, research and production. - ISSN 1213-2489. - Vol 14, No. 3 (2014), pp. 375-380.

[12] SÁGA, M., JAKUBOVIČOVÁ, L., HANDRIK, M. (2014). Vehicles vibration analysis considering uncertain system parameters. In: Innovations in the concept, design, manufacturing and testing of freight wagons I: 27 - 28 November 2014, Žilina: Proceedings, University of Žilina, 2014. - ISBN 978-80-554-0955-9. - pp. 111-118.

[13] SIMPACK A.G. (2014). Documentation to the program system SIMPACK.

[14] Stability investigation of the overall support ELH 3-25. Internal document of LogoMotive GmbH company.

Copyright (C) 2017. Published by Manufacturing Technology. All rights reserved. 